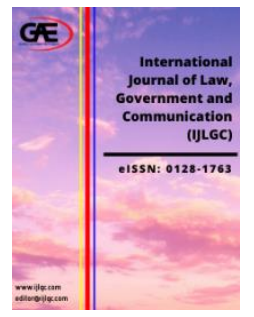

\author{
International Journal of Law, Government and \\ Communication (IJLGC) \\ Journal Website: http://ijlgc.com/ \\ eISSN: 0128-1763
}

\title{
AN OVERVIEW OF THE BANKING SYSTEM IN SYRIA AFTER A DECADE OF UNREST
}

\author{
Omar Farouk Al Mashhour ${ }^{*}$, Muhammad Imam Asalie ${ }^{2}$, Ahmad Shamsul Abd Aziz ${ }^{3}$, \& Nor \\ Azlina Mohd Noor ${ }^{4}$
}

1 School of Law, Universiti Utara Malaysia, Malaysia

Email: attorneyomarmash@gmail.com

2 Islamic Business School, Universiti Utara Malaysia, Malaysia

Email: imam.assalieh@gmail.com

3 School of Law, Universiti Utara Malaysia, Malaysia

Email:sham@uum.edu.my

4 School of Law, Universiti Utara Malaysia, Malaysia

Email: norazlyna@uum.edu.my

* Corresponding Author

\section{Article Info: \\ Article history: \\ Received date: 02.03 .2020 \\ Revised date: 21.04 .2020 \\ Accepted date: 20.05 .2020 \\ Published date: 10.06 .2020 \\ To cite this document:}

Al Mashhour, O. F., Asalie, M. I., Abd Aziz, A. S., \& Mohd, N. A. (2020). An Overview of The Banking System in Syria After A Decade of Unrest. International Journal of Law, Government and Communication, 5 (19), 68-84.

DOI: $10.35631 / / J L G C .519005$.

\begin{abstract}
:
After a decade of crippling international sanctions and devastating conflict, the Syrian economy has been largely in shambles. Nevertheless, the Syrian banking industry has largely weathered the storm. This article attempts to illustrate a comprehensive view of the banking sector in Syria and how well has one of the oldest banking systems in the middle east fared over the years and how has it survived the seemingly insurmountable challenges. Additionally, The article targets to show the role of the central bank of Syria in supervising the banking industry as well as a view on the recent development of the legal and financial orientation. The researchers have faced issues related to the absence of information due to its limits on what the central bank is publishing. Also, it is found that lack of English annual reports and missing reports for some years, will lower the chances of attracting investors. The article suggested a set of recommendations that may elevate the condition of the Syrian banking system by issuing a new law enforcement division to track down any unlawful activities.
\end{abstract}

\section{Keywords:}

Central Bank of Syria, Syrian Banks, Governance, Legislations, Syrian Pound, Financial Reports, Decree

\section{Introduction}

Providing a robust financial infrastructure that can assist the private and governmental projects has always been the ultimate goal for any economy. The prerequisite for a growing Copyright $\odot$ GLOBAL ACADEMIC EXCELLENCE (M) SDN BHD - All rights reserved 
economy is a healthy banking sector that offers a variety of services with the banks' financial performance by higher profitability (Hamza \& Khan, 2014). The theory of economic growth according to (Schumpeter, 1949), considers the bank to be one of the most important financial institutions that contribute in improving the productivity of the economy in addition to being an essential source of fund. Therefore, banks play a crucial role in the development of each countries' economy. The importance of the banking sector derives from its role in attracting depositors and providing loans for investors to support and increase the investment and the production of the country as well as participate in achieving growth in all the sectors of the economy (Rudevska \& Khlan, 2019). Hence, the banking sector plays a pivotal role in any economy, and failure of the banking system is likely to have dire consequences on the entire economy.

\section{Problem Statement}

In Syria, the banking sector was for many years owned and run by the public sector through a number of banks of different types and tasks until the private banks were established and licensed under decree No. (28) of 2001. The Syrian banking sector has gone through several stages of vicissitudes during the ongoing war that has considerably affected Syria's economy and left it in unenviable condition (Al-Jafari \& Alchami, 2014). In the corporate world, annual reports are the most significant component for understanding the solvency, strengths, and strategies of each bank or company. Having access to comprehensive annual reports enables investors to make accurate, well-informed and swift decisions. Scarcity or unavailability of financial information creates a foggy environment that are likely to scare away most of potential investors. This situation will eventually reflect on the financial visibility of the investors and deprive the banks of potential growth (Antalóczy, Sass \& Szanyi, 2011).

Before and after the outbreak of the war, there was a huge lack of information, data, and researches about the banking sector in Syria. The bulk of information available about the Syrian banking sector was confined to some official publications released by the Central Bank of Syria (CBS) and official newspapers. There is a marked paucity for academic articles targeting the Syrian banking industry. The existing research results are limited and outdated, which makes them irrelevant and of little use for explorers or research workers. This absence of information regarding the Syrian banking sector represents a problem for researchers in their evaluation process of the sector. In addition, the absence of enough annual reports in English has discouraged many investors to invest their money in the Syrian banks due to the lack of sufficiently adequate information about the banking sector and its development in light of the current situation.

This article attempts to provide an overview of the Syrian banking system and its components. It also outlines the banking sector under the current situation. Reaching that goal requires an explanation of the entire banking sector and its different types and functions. The research also aims to see whether the current banking practices are in keeping with the global ones.

\section{Research Significance}

The importance of this research emanates from the scarcity of information provided in regards to the banking sector in Syria and related structure as well as the current status. The research explains the current banking structure and the applied laws and regulations. It also explains the rationale behind the establishment of each of them. It also provides an overview of the latest situation of the Syrian economy and its reflection on the value of the currency. 
The research also provides a number of recommendations that can be considered essential in order to improve banking practices and achieve more productivity and transparency in this highly important sector. Furthermore, we will shed light on the performance of the Syrian banking industry in order to work up the appetite of future researchers to produce more valuable information about the Syrian economy in general. The information presented in this article could hopefully act as an eyeopener for the authorities to take corrective actions and to strengthen the role of the Central Bank of Syria.

\section{Central Bank of Syria (CBS)}

The central bank of Syria was established on March $28^{\text {th }} 1953$, under the legislative decree No. (87) of 1953, which clearly identifies its duties and responsibilities. In addition, the above-mentioned legislation focused on publishing a new currency called the Syrian Pound or Lira. Decree 87 was later repealed and replaced by Law No.(23) of 2002 and its amendment (Legislative decree No. (21) of 2011) was introduced and is still applied until the present time.

As an essential part of CBS, the Credit and Monetary Council (CMC) enjoys top-notch experts working within the council. The objectives of CMC are concerned with crafting strategic monetary policies that are capable of achieving financial goals at the national level. In addition, the committee is responsible for setting interest rates to be followed by the operating banks in Syria (CGAP, 2008). Moreover, within the CMC, Shariah Advisory Board was established to advise the central bank regarding any Shariah issues related to Islamic financial businesses or activities made by the bank (CBS, 2020).

On the first of April of 2009, CBS has issued comprehensive governance guidelines for the licensed banks to promote the application of high standards of corporate governance. The guidelines imposed duties on the operating banks to publish their annual reports in Arabic and English and to present sound financial reports that aim to use proper financial analysis without delay. In addition, they laid down the roles and procedures for internal and external audit committees (CBS, 2009). According to Law No. (23) of 2002 and the Legislative Decree No. (21) of 2011, the tasks and duties of the Central Bank of Syria are as follows:

\section{Roles and Functions}

1- Issuing the Syrian national currency:

The central bank of Syria is holding the exclusive legal right to issue and manage the Syrian currency accordingly.

2- Ensuring a robust and resilient financial sector:

CBS is the official authority responsible for creating and fostering a sound and progressive financial sector.

3- Developing and strengthening the Syrian financial infrastructure:

One of the major roles of CBS is to expand the access to finance and financial services to all segments of society. Consequently, CBS established different types of public banks such as the Commercial Bank of Syria, Real Estate Bank, Agro Bank, and others.

\section{Monetary and Economic Policy}

1- Enhance the formulation of monetary and credit policies, including issuance of national bonds and contribution to the international financial negotiations as well as managing the country's international reserves 
2- Promote monetary policies that ensure the availability of adequate credit to finance economic growth and financial crises

3- Ensure a high level of security in all financial activities through compliance with the law

4- Implement strict legal policies against money laundering and terrorist financing activities

5- Monitor financial transactions with non-banking institutions such as exchange providers and insurance operators to ensure compliance with the national economic goals

\section{Supervision}

1- The central bank is the master of all banks in Syria. It monitors and the regulates the entire monetary policy, including lending and evaluating its adaptation to the national economy.

2- It supervises and administers the duties of all the public and private banks operating in Syria.

3- $\mathrm{CBS}$ is also responsible for providing and implementing an effective surveillance framework to ensure financial stability in all aspects.

\section{Public Banks in Syria}

Until the first decade of 2000, the whole banking sector in Syria consisted of the state-owned banks such as the Commercial Bank of Syria, and other specialised banks (the Agricultural Cooperative Bank, Industrial Bank, Real Estate Bank, and Popular Credit Bank) (Sukkar, 2018).

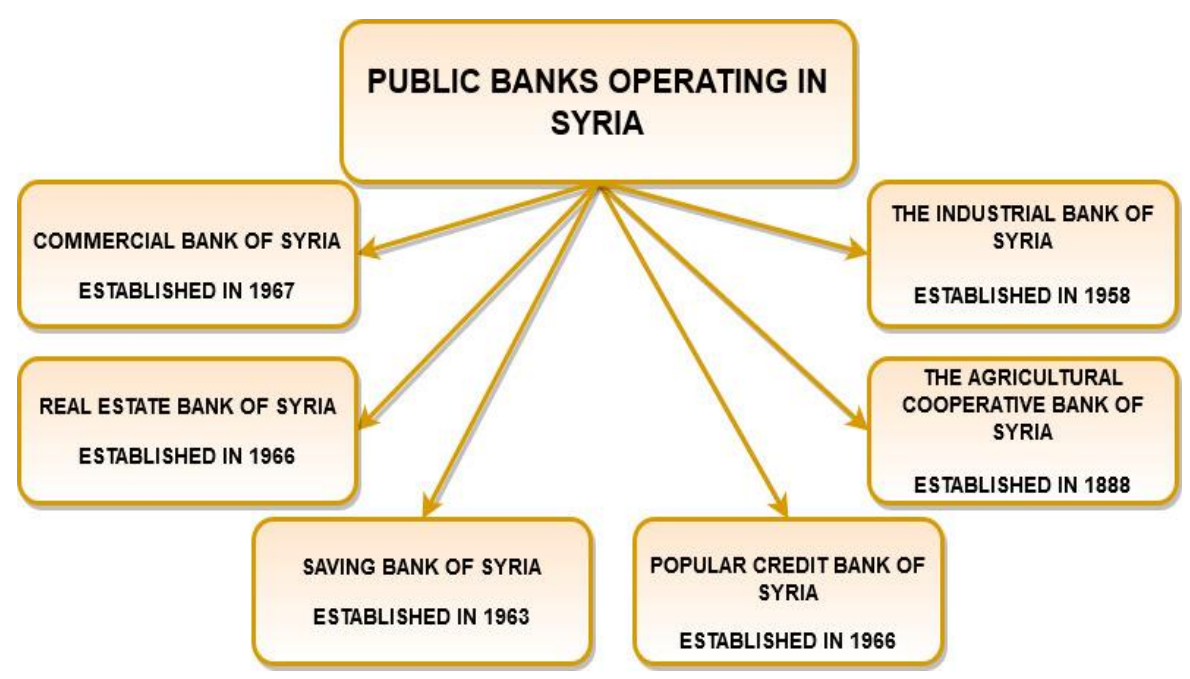

Figure 1. The Public Banks Operating In Syria

Source: The Researchers, based on the information provided by the government official websites.

All public banks in Syria enjoy legal personality and independent financial and administrative status. Broad managerial powers were given to the public banks, including control the shortand long-term credit and acceptance of deposits. Public banks are practically linked to the Ministry of Finance (MoF). They are also subject to CBS supervision and authority, under Legislative Decree No. (21) of 2011. 


\section{Commercial Bank of Syria}

The Commercial Bank of Syria is one of the largest banks in Syria, accounting for the largest volume of banking activities and more than $70 \%$ of the deposits and loaning activities in the market (CBS, 2020). The bank was established in accordance with the enactment of Legislative Decree No. (913) of 1966. The legislation has provided for a regulatory capital amounting to 150 million Syrian Pounds at the early stage of its establishment. Later, the figure was gradually increased under the Council of Ministers' Orders No. (340) of 1993 and (7) of 1998 to reach 4 billion Syrian pounds. Recently, the regulatory capital has increased significantly under the new Legislative Decree No. (35) of 2006. It increased the capital to 70 billion Syrian Pounds. Article (4) of the decree states the main financial sources of the bank and its assigned tasks and objectives. Article (10), (13), (14) of the decree provides for the guarantees and banking rights against the others.

\section{Real Estate Bank of Syria}

Since its establishment, the Real Estate Bank has been one of the time-honoured financial institutions in Syria that provides its customers with varieties of banking services. The bank has specific goals, including support and enhancement of the urban movement in addition to increasing the number of housing projects and tourist, health and educational facilities through financing such activities (REB, 2020). With the enactment of the Legislative Decree No. (29) of 1966, the Real Estate Bank of Syria was established, and 15 million Syrian Pounds was required as regulatory capital. However, the new Legislative Decree No. (31) of 2005, introduced some amendments whereby the regulatory capital was increased to 1.5 billion Syrian Pounds. As in the Commercial Bank, the decree also stated the tasks and services provided under Articles (4) and (5). Similarly, Articles (10), (11), (12), (13) of the decree also provided the same guarantees by way of securing its right before its clients.

\section{Saving Bank of Syria}

The Saving Bank of Syria was established in 2001 with the ultimate goal of accepting and managing saving deposits for its customers (CGAP, 2008). The bank was often referred to as "The Postal Savings Bank". Later on, the bank was transformed to become Saving Bank of Syria with the enactment of Decree No. (485) of 2000. Recently, a new Legislative Decree No. (29) of 2005 has been issued, with amendments introduced to the previous law. Article (2) of the latest decree has set a regulatory capital amounting to SP 1.5 billion for the bank.

Besides providing the regular banking services, Article (5) of the Act identified the missions and duties of the bank. The bank aims to boost the economic cycle through banking facilities and loans to the natural and legal persons for a short, medium or long-term and financing educational medical, tourist, industrial and small-scale business activities such as financing universities, colleges, institutes, hospitals and other small clinics (SBS, 2020 ). The bank also finances other projects that are stated in the investment Act of 2007

\section{Popular Credit Bank of Syria}

Popular Credit Bank is one of the government-owned banks established by Legislative Decree No. (64) of 1966, which was later amended by Legislative Decree No. (32) of 2005. Under Article (2) of the decree, the required regulatory capital amounts to 1.5 billion Syrian Pounds. According to Article (4) and (5) of the decree, the bank provides retail banking services and targets several categories, such as traders, professionals, artisans, and industrialists. In addition, the bank's services cater for low-income people as well as industrial enterprises and small and medium tourism enterprises. Additionally, the bank grants loans to purchase state-produced cars (Cham, Saba, Siamco) and finance solar energy 
systems across the country (PCP, 2020). As in the other public banks, the Decree came with the same guarantee stated under the previous decree regarding the services delivered to persons such as loans etc.

\section{The Agricultural Cooperative Bank}

For centuries, the Syrian economy has relied on the agricultural sector as the backbone of the Syrian gross domestic product (Alloush, 2018). Since its establishment on 15 August, 1888, the agriculture-cooperative bank has been the pioneer in financing the Syrian agricultural activities (Al-wehda, 2018). The bank is specialised in offering agricultural credits and has played a vital role in the agricultural development process in Syria (CGAP, 2008). According to (ACBS, 2020), the economic and financial developments that happened locally and globally, have imposed a duty on the bank to do a reconsideration and revision of the policies and their working mechanism. Therefore, Legislative Decree No. (30) of 2005 has introduced some major changes in the operation of the bank to achieve better compliance with the changes that have occurred in the CBS regulations and the other related banking laws. According to Article (4) of the Legislative Decree No. (30) of 2005, the required regulatory capital for the bank has been modified to be 10 billion Syrian pounds. Like other public banks, Article (5) of the decree lays down the financial sources of the bank. Moreover, the law provided the bank with many guarantees under chapter (3) and (4) of the decree. Moreover, the bank has given a privilege under section (13) in which all bank cases or legal procedures have priority over other cases or procedures.

\section{The Industrial Bank}

The Industrial Bank of Syria is the only public bank created to provide loans for both public and private industrial projects to contribute to the advancement of the national economy. The bank has been established under Decree No. (177) of 1958 with 12.5 million Syrian pounds set as regulatory capital. However, with the enactment of parliament Law No. (28) of 2010, the required regulatory capital was increased to 10 billion Syrian pounds.

Article (5) of the decree has set some specific functions of the bank as follows:

1. Providing credit facilities for a long-term investment for up to fifteen years.

2. Providing various banking services, including carrying out external operations of the Bank's customers, in a manner that serves the local international traders.

3. Participating in national financial visions and trading of securities. 


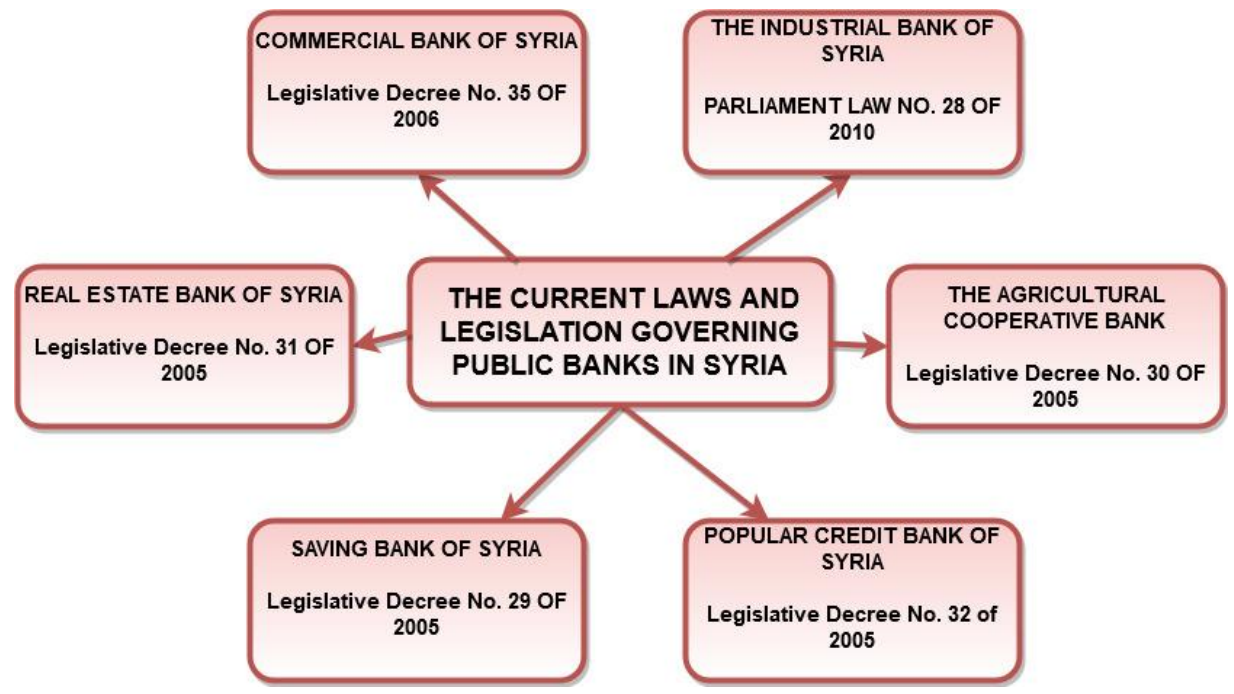

Figure 2. The Current Laws and Legislations Governing Public Banks in Syria

Source: The Researchers, based on an investigation on the latest published laws and legislation.

\section{Syrian Private Banks}

After decades of dominating the entire Syrian banking sector, in 2001, the Syrian government took a corrective move by issuing a set of laws to license, organise, and regulate private banks. In light of these changes, new laws were promulgated, allowing the private sector to be part of the banking sector in Syria as a positive step towards a healthy banking system.

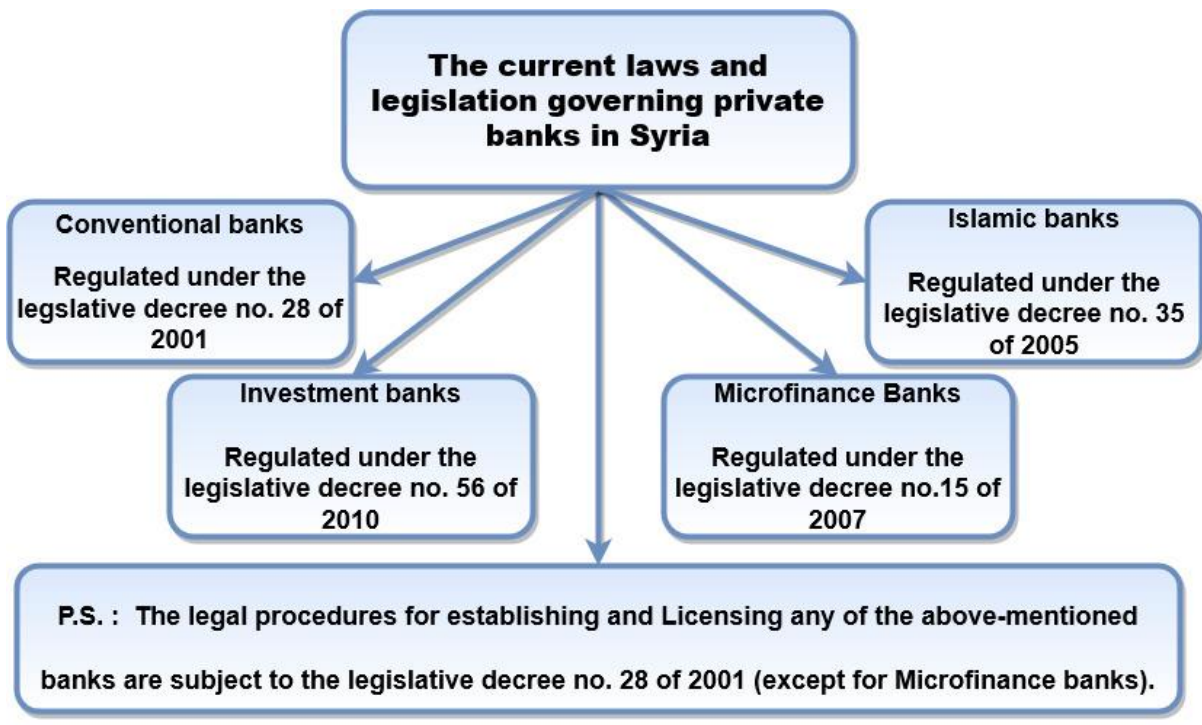

Figure 3. The Current Laws and Legislations Governing Private Banks in Syria Source: The Researchers, based on an investigation on the latest published laws and legislation.

Private Banks in Syria were established under Decree No. (28) of 2001. The establishment of the private banking sector ushered in an end of the state monopoly and control over the banking sector. In addition, the establishment of Islamic banks, investment banks and Microfinance banks were introduced by Decree No. (35) of 2005 (Islamic banks), Decree No. (56) of 2010 (investment banks) and Decree No. (15) of 2007 (Micro-finance banks). At the present time, the banking sector in Syria consists of 15 banks (Islamic, Conventional, Investment and micro-finance banks) which are subject to the supervision and guidance of 
the Central Bank of Syria. Private banks, like their state-owned counterparts, report to the CBS.

Decree No. (28) of 2001 contained some provisions that restrict the functioning of foreign investors by having more than $49 \%$ of the total shares of the companies. However, with the new amendment that has been made by Decree No. 3 of 2010, Article (3), the Council of Ministers decided to increase the percentage to $60 \%$ of the total shares. The regulatory capital for the private bank under the law was not less than 1.5 billion Syrian Pounds. However, with the new amendment No. (3) of 2010, the figure has been increased to 10 billion Syrian Pounds. The private banks have additionally contributed to an overall improvement in the quality of financial services by putting competitive pressure on state banks.

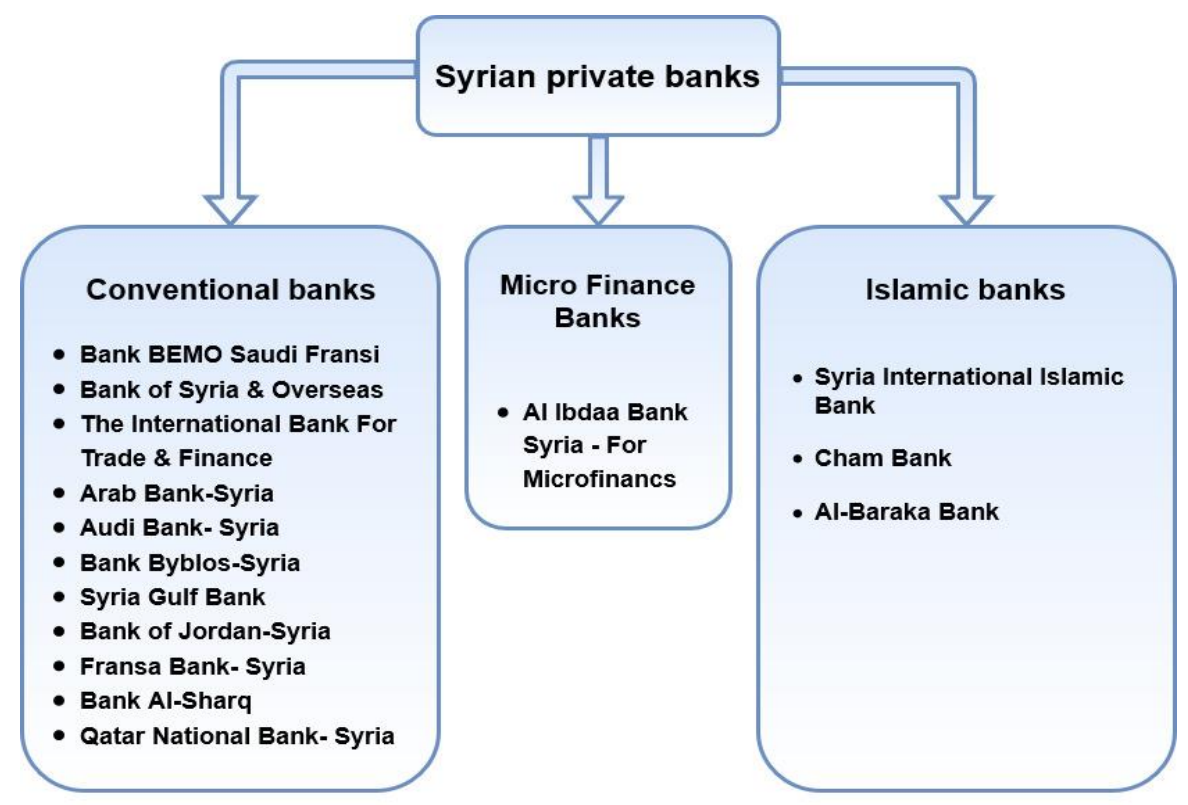

Figure 4. Syrian Private Banks

Source: The Researchers, based on the information provided in the official state websites.

\section{Islamic Banks in Syria}

The development of Islamic finance industry has steadily and rapidly grown and expanded over the past decade, with a significant growth rate reaching up to $12 \%$ annually (Alawode, 2015). However, this massive rapid sprouting of Islamic financial services was constrained due to political conflicts that occurred in the Middle East especially in countries like Syria, Iraq, Lebanon, and Libya (DIB, 2017). The emergence of the long-awaited Islamic banks in Syria filled the need of the Muslim community and presented an alternative option and a serious competitor for the conventional banks (CGAP, 2008). Unfortunately, the Syrian Islamic banking industry had started belatedly when legislative Decree No. (35) of 2005 was issued. Compared to its peers in the Middle East, like the United Arab Emirates, Jordan and Turkey, which were pioneers of Islamic banking system in the region, like "Dubai Islamic Bank (1973), Jordan Islamic Bank for Finance and Investment ( 1978), and Al-Baraka Turkish Finance House Inc. (1985), the Syrian Islamic banks were established much later .

In 2005, Legislative Decree No. (35) was issued under which three Islamic banks were licensed; namely, Syria International Islamic Bank (SIIB), Cham Bank (CB) and al-Barakah Bank Syria (BBS). These few Syrian Islamic banks have successfully captivated a large 
number of customers, thanks to their integrated Islamic financial system and application of Sharia law of its banking transactions which is away from 'Riba' (usury), 'Gharar' (ambiguity), and 'Maysir' (gambling) concepts. As the Islamic banking services are adhering Islamic law, there are restrictions in dealing with forbidden commodities such as alcohols, pork, pornography etc. The Islamic banking industry in Syria has robust legislation that governs the Shariah compliance, capital adequacy standards, and Islamic auditing over Islamic banking services. Besides, the laws emphasised that any Islamic banking services should be subject to the shariah principles (CGAP, 2008).

The internal structure of the three operating Islamic banks in Syria is complying with the Islamic Shariah standards and subject to an internal Shariah committee supervision. In 2011, the Syrian Islamic banks had 42 branches across the country and achieved a net profit exceeding 30.8 billion Syrian pounds in 2016 (CBS, 2020), which points to a very productive financial performance compared to the conventional local banks.

Several challenges have faced the Islamic banks operating in Syria, posing a serious pressure on their financial positions due to the following reasons:

- The Islamic banks in Syria were required to pay 15 billion Syrian Pounds as regulatory capital for each Islamic bank to the Central Bank of Syria, compared to 10 billion Syrian Pounds for conventional banks.

- Intense market competition with conventional banks in both public and private banks.

- The Islamic banking industry in Syria is still at the novel stage as the first Islamic bank in Syria started operating in 2006 (Mhanna \& Ammar, 2017).

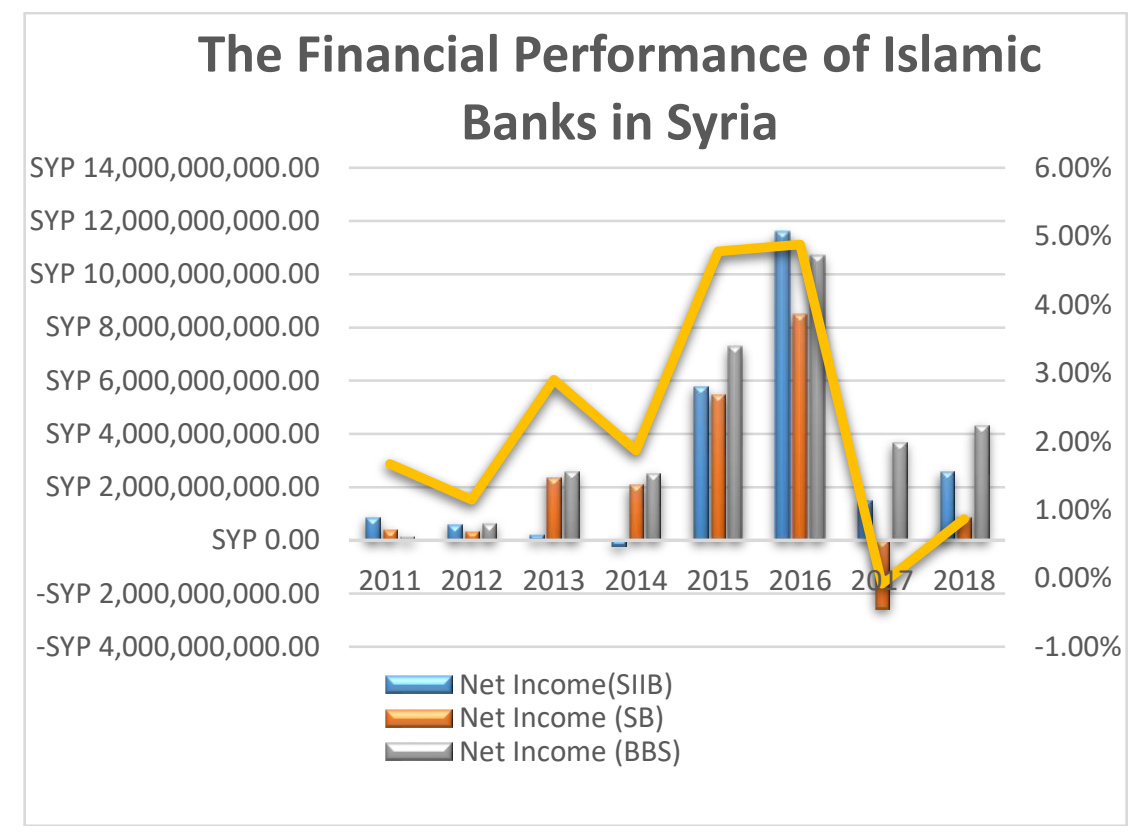

Figure 5. The Financial Performance of Islamic Banks in Syria

Source: The Researchers, based on the annual financial reports published by the Islamic Banks in Syria between 2011 and 2018.

In the finance language, the higher return on assets (ROA) is a tell-tale indicator of a robust financial and operational performance (De Wet \& Du Toit, 2007). The above figure clearly shows massive fluctuations in the ROA percentage in between 2011 to 2018, which 
represents a strong sign that the Islamic banks in Syria are facing a financial problem related to generating an adequate return on the assets they have, rather than relying entirely on the return on sales. Until today, the assets of the Syrian Islamic banks continue to grow, which requires a high level of net income. As a healthy return on assets explicitly determines how efficiently the bank can squeeze profits from its assets.

\section{The Main Laws Governing the Banking Sector In Syria}

\section{Banking Laws and Legislations}

In Syria, banks are divided into public sector banks and private banks. Each bank is regulated with a decree enacted to identify and regulate all the internal affairs of the bank such as the function, mission, objectives and the structure of each bank. In the public sector, each bank is regulated by a separate decree such as Legislative Decree No. 35 of 2006 regulating the commercial bank of Syria.

In the private sector, on the other hand, the Syrian legislator also introduced several legislations under which several types of private banks were established, such as the decree on establishing the Islamic bank and another on establishing the investment bank and many others.

\section{Monetary Act No. (32) of 2002 and its Amendments (Legislative Decree No. 21 of 2011)}

The Monetary Act No.(32) of 2002 and its amendments introduced the Monetary Council, which aimed to achieve several objectives, including maintenance of the purchasing power of the Syrian currency, regulation and development of money and financial markets in addition to many other objectives. Besides, the Monterey Council is responsible for regulating and supervising the banking sector activities, discussing all related issues, taking appropriate decisions in coordination with the Central Bank and monitoring the banking profession. The Act also states that bank licenses can be withdrawn if the bank doesn't follow the provisions stated therein.

\section{Bank Secrecy Act of 2010}

The functions and powers enshrined in this Act cover all financial institutions operating in Syria including the one located in the free zones. The Act identifies its scope of work and the information that is considered confidential and should be protected as follows:

1. The identity of the clients and information and detail about his account and assets.

2. The transactions that the Client makes at the concerned financial institution

3. The safe deposit boxes and the numbered accounts that are only known to the head of the institution, or the person authorized by him.

The Act sets penalties for breaching any of its provisions and provides for the exceptional cases in which the provisions of the Act does not apply.

\section{Companies Act of 2011}

The provisions of this Act apply to banks in regard to licensing, board of directors, directors and the mechanism for holding meetings and all the other matters related to companies as a legal entity and management. The banks are also subject to the supervision by the company departments which appoint a representative to attain and supervise all the meetings and resolutions of the General Assembly. 


\section{The Commercial Code of 2007}

Section (6) of the Act characterizes all banking activities and transactions as commercial activities under the Act. Accordingly, banks are required to abide by the provisions of this Act. The Act also states the requirements for practising any commercial activity and regulates commercial contracts, instruments and transactions. Moreover, the Act identifies the rights and obligations of the person or the company practising a commercial activity. In addition, it provides for establishing an office in each governorate ( province) called "The Commercial Registry Office" and requests traders to register all their businesses and related contracts, transactions and other important related matters such as insurance, access rights, transfer rights and many others.

\section{The Civil Code of 1949}

It is the mother of all rights and the mainstay of all laws and regulations, from which all legislations and pertinent laws ramify. Civil Law is considered a general law because it contains the general rules and principles that regulate and govern the legal relationships among individuals, regardless of the nature of these relationships and the status of these individuals. The commercial law, on the other hand, is considered a special law in comparison with the civil law given that its provisions aim to exclusively regulate and govern businesses and businesspersons and how to reconcile the provisions of the two laws. When a business matter is brought to court, the judge must primarily seek a solution thereto in the commercial law and should he fail to find an appropriate provision, he has to refer to the general rules stated in the civil law.

In addition to the above-mentioned law, there are many other laws and legislations that apply to banks such as the civil procedures Act, and Law No.(21) of 2014 under which banking courts were established and Land Registry Act in addition to other legislations enacted to facilitate the activities of private banks.

\section{Banking Courts}

The need for establishing banking courts was based on the principle of judicial specialization and the importance of disposal of arising banking cases and facilitation of their procedures. For that purpose, Laws (21) of 2014 and (19) of 2014 on the creation of banking courts and executing banking instruments had been promulgated. The establishment of banking courts aimed to ensure quick, streamlined and flexible completion of procedures in addition to safeguarding the interests of litigating parties, protecting banks' funds and collection of banking debts.

Section (1) of the law provided for establishing banking courts of the first instance and appeal in each province. The banking courts ( first instance and appeal) which were created under Law 21, dated 5/11/2014 are empowered to consider banking cases whose involved party is a bank or a financial institution that accept deposits and sanction credit facilities controlled by the Currency and Credit Council. The decisions taken by the court of appeal are considered final and conclusive.

Section (3) of the Law empowers the courts to take appropriate action and urgent decisions like travel bans. These courts may also rescind any of these steps at the request of the party that has been affected by these measures. The provisions of this action and the pertinent decision are subject to appeal before the banking court of appeal. These measures may be taken by the judge in case the borrower or the defendant does not have sufficient solvency and serious assurances to repay the outstanding loan amount. 


\section{The Current Economic Situation}

The Syrian economy depends primarily on services, agriculture, oil and industry. A look at Syria's economy during the $60 \mathrm{~s}$ reveals that the country experienced marked GDP development and expansion, reaching up to $80 \%$ (Kahwaji, 2018). It peaked up to $336 \%$ during the 1970s (World Bank, 2018). However, this trend has not maintained its upward tendency, and the economy shrank by 33\% during the 1980s. However, the GDP per capita registered a very modest total growth of $12 \%$ (1.1\% per year on average) in the 1990s, thanks to successful diversification of the country's economy.

The ongoing war in Syria is one of the most devastating crises worldwide. The destructive dramatic development has heavily impacted several aspects of the national economy and has imposed a negative effect on the Syrian financial system (Abdulrahim \& Osseiran, 2020). Before the political crisis of 2011, Syria's economy and financial situation experienced a rapid and improved tendency. GDP grew at an average of $4.3 \%$ per year, helped by non-oil sectors with a rate of inflation averaged at 4.9\% (Calì \& Harake, 2015). The Syrian Center for Policy Research (SCPR) and UNDP report indicate that the loss in Syrian GDP relative to the "no war" counterfactual alone is estimated at \$200-300 billion (Devarajan \& Mottaghi, 2017).

In the years that followed the civil war, specifically in 2012, GDP recorded at USD 4684.72 (World Bank, 2017). The negative effects of the Syrian civil war on economic growth have been colossal and were marked by a decrease in per capita income by more than $38 \%$ from 2012 to 2015 according to (CIA, 2018) and more than $80 \%$ of people living in poverty in 2019 (McKernan, 2020). With the economy already in dire straits, the cost of fighting Coronavirus disease (COVID-19) and applying precautionary measures is difficult to bear. The Syrian finance minister announced that the government would spend 100 billion Syrian Pounds to fight the pandemic, equivalent to USD 60 to 65 million, or about USD 3.5 per person (Al-Adawi, 2020). This sum is an indication of just how little the Syrian economy has left in reserve.

\section{Syrian GDP}

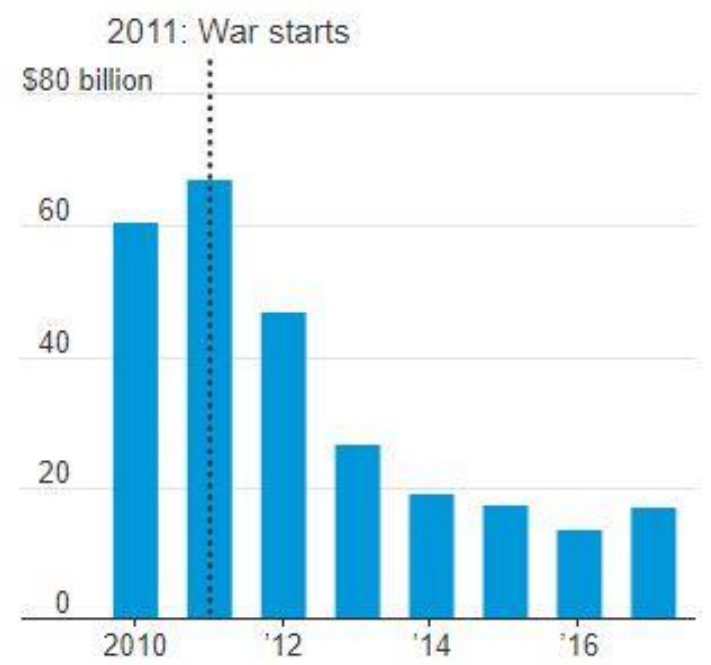

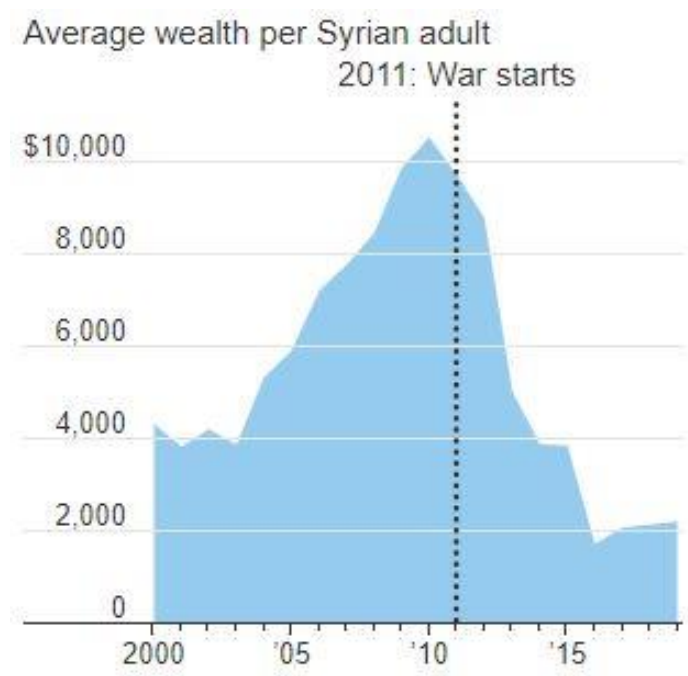

Figure 6. The Syrian GDP and the Average Wealth per Syrian Adult Source: World Bank Website. 
After nine-years of a devastating war, the Syrian economy, which is shunned by foreign investors and strangled by western sanctions faces enormous challenges to recover. The ongoing war has destroyed roads, hospitals and other vital infrastructures, while many businesses and factories have closed in the major economic city of Aleppo, in addition to the mass destruction that hit governorates like Homs and Damascus Countryside. Heavy international sanctions have made it exceedingly difficult to import basic items and enable trade to deal with the outside world.

\section{The Syrian Pound (SYP)}

The Syrian pound was linked to the French Franc until Syrian joined the International monetary fund in 1947 and established a par value equivalent to 2.19 to 1 US dollar. In 1948, the Syrian Pound was officially separated from the Lebanese Pound, and became the only official currency in circulation, although the actual separation happened in 1950. Under Legislative Decrees No. (23) of 1949 and (76) of 1950, the Syrian Monetary Law has given the Syrian government the privilege to be the only issuer of the currency in Syria. The government then established the Syrian Monetary Agency, which was responsible for the printing notes and minting coins. After that, the Central Bank of Syria was introduced under the legislative decree no (87) of 1953 but was not actually established until 1965.

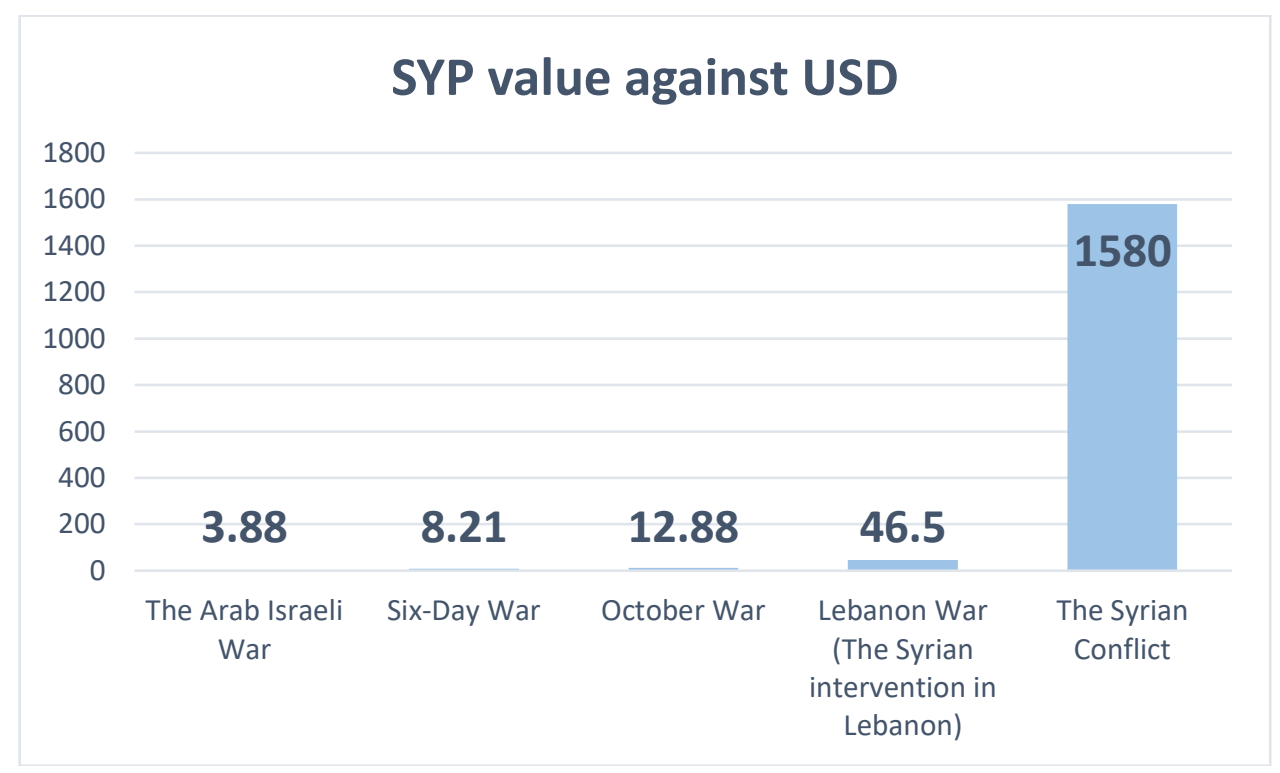

Figure 7. The Syrian Pounds against the US Dollars

Source: The Researchers, based on the latest statistics published by both national and international bodies.

The infographic mentioned above illustrates the depreciation of the Syrian currency over the past 100 years. The Syrian Pound had gone into a series of trouble since its establishment. From the seventies to the eighties, the exchange rate fluctuated between 3.65 to $12 \mathrm{SYP}$ for 1 USD. During the nineties, the exchange rate dropped down to 48.55 SYP for 1 USD. Following the fall of the Syrian economy as a result of 9 years of civil war, the value of the Syrian pound has plumbed to 1221 SYP for 1 USD in 2020. Before going deep into details, the researchers found that the history of the Syrian pound has always confirmed that the plunging of its value has always been caused by devastating wars.

When the Syrian conflict erupted in March 2011, the US Dollar was valued at 47 Syrian Pounds. Currently, it traded at around 1,100 Syrian pounds at some exchange shops (MEO, 2020). Syria has relied heavily on its neighbour Lebanon for access to foreign currencies and to pay for imports in an effort to counter U.S. and European sanctions on the Syrian Copyright $\odot$ GLOBAL ACADEMIC EXCELLENCE (M) SDN BHD - All rights reserved 
government. However, with the present situation in Lebanon has plunged in political and economic crisis, Lebanese banks in September 2019 imposed limits on overseas transfers and a cap on the withdrawal of U.S. dollars, which raises the Syrian conflict cost to a new record (Al-Khalidi, 2020).

The Syrian government, at the beginning of 2020, has taken stringent measures to crack down on the black market. The Presidential Decree No. (54) of 2013 and its amendment No. (3) of 2020 has banned the use of any currency other than the Syrian Pound. Money exchange houses are also coming under scrutiny, with the Syrian government cracking down on those accused of price gouging. According to local Syrian media reports, the government has shut down several exchange offices accused of driving up the exchange rate at the black market (Sabbagh, 2020).

\section{Recommendations}

There are a set of recommendations that are highly needed to achieve the prosperity of the Syrian banking industry. Firstly, the central bank of Syria should set a standard annual report format and deliver it to all banks in Syria in order to enhance the quality of the financial figures represented. Also, CBS should impose penalties for the delay in disclosing the annual reports and the technical errors related to non-justified financial results. Secondly, there is an urgent need for the Syrian banking industry to publish valuable information in English to boost the chances of attracting international investors. Thirdly, there is an urgent need to activate the supervisory role of the Central Bank of Syria over the entire banking sector to ensure banks' compliance with the governance guidelines and all the provisions of the enacted legislations. After analysing the annual reports of several banks, the researchers can find vogue financial errors that must be investigated by CBS. It has been found that many banks have not submitted or delayed the submission of their annual reports for some years. In addition, the Syrian government is highly advised to allow public banks to establish other Islamic banks subsidiaries.

Due to the vital importance of law in boosting banking performance, it is advised that the Syrian laws on banking should be revised and amended to address the current issues that have arisen due to the on-going war. After more than nine years of war, the Syrian legislator should provide more accurate and appropriate provisions that can achieve stability in the Syrian banking sector. Moreover, the Syrian legislator must empower the central bank with wider authority over the entire banking sector, including the public banks. For instance, the majority of private and public banks do not fulfil their legal obligation to meet their threeyear regulatory capital as stated in the law.

In 2009, the Central Bank of Syria issued comprehensive governance guidelines for all the banks operating in Syria. However, several banks failed to comply with that guidance. For example, many public banks did not publish their annual reports in English or did not even disclose any annual reports for many years. Disclosure of the financial information for the operating banks in Syria should be adhered to through following the laws and guidance issued by the Central Bank of Syria. It is also suggested that CBS should establish a specific legal enforcement division in order to track down any unlawful activities from the operating banks. Additionally, the Syrian legislator should prepare the market players for the upcoming revolution in finance, as financial technology (Fintech) is introducing new innovative ways of finance, requiring a robust financial infrastructure. 


\section{Conclusion}

According to the Central Bank of Syria, twenty-one banks are operating in the country. The six government-owned banks are dominating the market and are more than 70 years old. However, during the first decade of 2000, the Syrian government started licensing of private banks urged by the vision of enhancing the monetary capabilities of the country and bringing life to the wounded economy as a result of years of sanctions. In 2005, CBS did a corrective action by allowing Islamic banks to offer Islamic banking services to the Muslim Syrian communities. The dramatic fall of the Syrian pound to 22 times its value against the American dollar since 2011 was a result of nine years of brutal and devastating civil war. The decline of the Syrian pound highlights the vulnerability of the current financial system to shocks, which accentuates the contemporary banking crises in light of the shortage for the US dollar.

\section{References}

Abdulrahim, R., \& Osseiran, N. (2020). Reviving Syria's Economy Is an Uphill Battle for Assad After Years of War. The Wall Street Journal. Retrieved from https://www.wsj.com/articles/reviving-syrias-economy-is-an-uphill-battle-for-assadafter-years-of-war-11580497279.

ACBS. (2020). The services of the Agricultural Cooperative Bank of Syria. Damascus, Syria The Agricultural Cooperative Bank of Syria Retrieved from http://agrobank.gov.sy/services

Alawode, A. (2015). Islamic Finance. Washington D.C.: World Bank. Retrieved from https://www.worldbank.org/en/topic/financialsector/brief/islamic-finance.

Al-Adawi, W. (2020). Finance Minister: The necessity of strictness and non-tolerance in applying customs control mechanisms at the borders. Retrieved 16 May 2020, from https://sana.sy/?p=1125853

Al-Jafari, M. K., \& Alchami, M. (2014). Determinants of bank profitability: Evidence from Syria. Journal of Applied Finance and Banking, 4(1), 17.

Al-Khalidi, S. (2020). Syrian pound hits new lows over regional tensions - traders. Retrieved from https://www.reuters.com/article/syria-economy-pound/syrian-pound-hits-newlows-over-regional-tensions-traders-idUSL8N29I5PO

Al-wehda. (2018). The Agriculture Bank: How it provides its services. Retrieved from http://www.alwehda.gov.sy/index.php/\%D8\%A7\%D9\%84\%D9\%88\%D8\%AD\%D8 \%AF\%D8\%A9/61440\%D8\%A7\%D9\%84\%D9\%85\%D8\%B5\%D8\%B1\%D9\%81\%D 8\%A7\%D9\%84\%D8\%B2\%D8\%B1\%D8\%A7\%D8\%B9\%D9\%8A\%D9\%83\%D9\%8 A\%D9\%81\%D9\%8A\%D9\%82\%D8\%AF\%D9\%85\%D8\%AE\%D8\%AF\%D9\%85\%D 8\%A7\%D8\%AA\%D9\%87\%D9\%88\%D9\%8A\%D9\%88\%D9\%81\%D8\%B1\%D9\%85 \%D8\%B3\%D8\%AA\%D9\%84\%D8\%B2\%D9\%85\%D8\%A7\%D8\%AA\%D8\%A7\%D 9\%84\%D8\%A5\%D9\%86\%D8\%AA\%D8\%A7\%D8\%AC\%D8\%A7\%D9\%84\%D8\%B 2\%D8\%B1\%D8\%A7\%D8\%B9\%D9\%8A\%D8\%9F.

Alloush, B. (2018). The importance of the agricultural sector for Syria's stability. Retrieved from https://syria.chathamhouse.org/research/the-importance-of-the-agriculturalsector-for-syrias-stability

Antalóczy, K., Sass, M., \& Szanyi, M. (2011). 7 Policies for attracting foreign direct investment and enhancing its spillovers to indigenous firms: The case of Hungary. Multinational Corporations And Local Firms In Emerging Economies, pp. 181-210. doi: doi:10.2307/j.ctt46n0w0.10

Calì, M., \& Harake, W. (2015). The impact of the Syrian civil war on its neighbours: the trade channel. World bank blogs. Retrieved from 
https://blogs.worldbank.org/arabvoices/impact-syrian-civil-war-its-neighbours-tradechannel.

CBS. (2009). Governance guidelines for banks operating in Syria. Damascus Central Bank of Syria

CBS. (2020). Shari'a Advisory Board (Commission). Damascus, Syria CBS

CBS. (2020). CBS - A Brief History Retrieved from http://www.cbs-bank.sy/index.php\#

CGAP. (2008). Policy and regulatory framework for microfinance in Syria Retrieved from Washington,

DC: http://documents.worldbank.org/curated/en/126971468132270230/pdf/434330WP0Sy ria10box032736801PUBLIC1.pdf

CIA. (2018). The World Factbook. Retrieved from https://www.cia.gov/library/publications/the-world-factbook/geos/sy.html

Devarajan, S., \& Mottaghi, L. (2017). The economic impact of the Syrian conflict: Estimate it yourself. World bank blogs. Retrieved from https://blogs.worldbank.org/arabvoices/economic-impact-syrian-conflict-estimate-ityourself.

De Wet, J., \& Du Toit, E. (2007). Return on equity: A popular, but flawed measure of corporate financial performance. South African Journal of Business Management, 38(1), 59-69.

DIB. (2017). Global Islamic Finance Report (GIFR) Retrieved from Dubai http://www.gifr.net/gifr_2017.htm

Hamza, S. M., \& Khan, E. A. (2014). Effect of banking sector performance in Economic growth Case study of Pakistan. Journal of Applied Environmental and Biological Sciences, 4(7), 444-449.

Kahwaji, A. T. (2018). Contingency Planning in Traditional and Islamic Banks During the Crisis in Syria: Crisis Management Perspective. European Journal of Islamic Finance(9).

McKernan, B. (2020). 'After war we now have this': Syrians grapple with poverty and coronavirus. $\quad$ Retrieved 16 May 2020, from https://www.theguardian.com/world/2020/apr/10/after-war-now-have-this-syriansgrapple-poverty-coronavirus

Mhanna, Z., \& Ammar, R. (2017). THE IMPACT OF BANKS CHARACTERISTICS ON FINANCIAL PERFORMANCE OF ISLAMIC BANKS: EVIDENCE FROM SYRIA. International Journal Of Advanced Research, 5(7), 1565-1573. doi: 10.21474/ijar01/4870.

MEO. (2020). Syrians feel sting of nosediving currency Retrieved from https://middle-eastonline.com/en/syrians-feel-sting-nosediving-currency

PCP. (2020). The objectives of the Popular credit bank of Syria. Damascus: Popular Credit Bank of Syria Retrieved from http://www.pcb-bank.sy/Information/objectives

REB. (2020). Tasks and Objectives. Damascus Real Estate Bank of Syria Retrieved from http://www.reb.sy/reb/en-us/aboutus.aspx

Rudevska, V. I., \& Khlan, Y. V. (2019). The Relationship Between Banking Sector $\begin{array}{lllll}\text { Development And } & \text { Economic }\end{array}$ doi:10.18371/fcaptp.v2i29.171868

Sabbagh, H. (2020). CBS shuts down a number of currency exchange companies. Retrieved from https://www.sana.sy/en/?p=183108

SBS. (2020). Services Retrieved from http://saving-bank.sy/\%d8\%ad\%d9\%88\%d9\%84$\% \mathrm{~d} 8 \%$ a7\%d9\%84\%d8\%a8\%d9\%86\%d9\%83/\#

Schumpeter, J. (1949). The Theory of Economic Development. 1934. Reprint. In (3rd ed.). Massachusetts: Cambridge: Harvard University Press. 
Sukkar, N. (2018). The Banking Sector in Syria in 2018. Retrieved from http://www.scbdi.com/en/Article83/The-Banking-Sector-in-Syria-in-2018.

The World Bank. (2017). The Toll of War: The Economic and Social Consequences of the Conflict in Syria. Washington, D.C: The World Bank.

World Bank. (2018). GDP (current US\$) - Syrian Arab Republic Data. Retrieved 16 May 2020, from https://data.worldbank.org/indicator/NY.GDP.MKTP.CD?locations=SY.

\section{The List of the Laws and Legislations:}

People's Council of Syria. Law no.23 (2002).

People's Council of Syria. Legislative decree no. 21, (2011)

People's Council of Syria. Legislative decree no. 29, (2005)

People's Council of Syria. Legislative decree no. 29, (1966)

People's Council of Syria. Legislative decree no. 30, (2005)

People's Council of Syria. Legislative decree no. 31 (2005)

People's Council of Syria. Legislative decree no.32 (2005)

People's Council of Syria. Legislative decree no.87 (1953)

People's Council of Syria. The parliament law no.28, (2010)

People's Council of Syria. Legislative decree no. 913, (1966)

People's Council of Syria. Legislative decree no. 35, (2006)

People's Council of Syria. Legislative decree no. 485, (2000)

People's Council of Syria. Legislative decree no. 64, (1966)

People's Council of Syria. Legislative decree no. 177, (1958)

People's Council of Syria. Legislative decree no. 35, (2015)

People's Council of Syria. Legislative decree no. 15, (2007)

People's Council of Syria. Legislative decree no. 56, (2010)

People's Council of Syria. Law no. 28, (2001).

People's Council of Syria. Legislative decree no. 23, (1949).

People's Council of Syria. Presidential decree no. 54, (2013). 